\title{
LIMITATIONS ON HIGH DATA RATE OPTICAL FIBER TRANSMISSION SYSTEMS DUE TO TRANSMISSION IMPAIRMENT
}

\author{
Final Report \\ $9 / 15 / 98-9 / 14 / 01$ \\ Curtis R. Menyuk \\ Department of Computer Science and Electrical Engineering \\ University of Maryland Baltimore County \\ Baltimore, MD 21250
}

March 15, 2002

Prepared for the US Department of Energy under grant no. DE-FG02-98ER14916

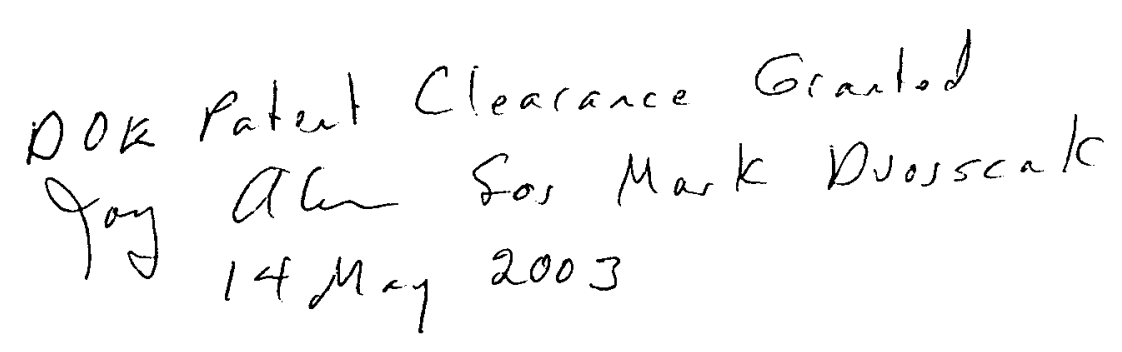




\section{DISCLAIMER}

This report was prepared as an account of work sponsored by an agency of the United States Government. Neither the United States Government nor any agency Thereof, nor any of their employees, makes any warranty, express or implied, or assumes any legal liability or responsibility for the accuracy, completeness, or usefulness of any information, apparatus, product, or process disclosed, or represents that its use would not infringe privately owned rights. Reference herein to any specific commercial product, process, or service by trade name, trademark, manufacturer, or otherwise does not necessarily constitute or imply its endorsement, recommendation, or favoring by the United States Government or any agency thereof. The views and opinions of authors expressed herein do not necessarily state or reflect those of the United States Government or any agency thereof. 


\section{DISCLAIMER}

Portions of this document may be illegible in electronic image products. Images are produced from the best available original document. 


\section{LIMITATIONS ON HIGH DATA RATE OPTICAL FIBER TRANSMISSION SYSTEMS DUE TO TRANSMISSION IMPAIRMENT}

The purpose of this grant was to supplement our regular Department of Energy grant in order to allow us to increase our interactions with industry. In particular, its purpose was to sponsor internships for our graduate students at industrial laboratories and to spark collaborations. I am not supplying a list of our publications with this report because they are included in our regular DOE grant reports.

\section{Accomplishments}

As previously noted in the previous grant report DOE/ER/14916-2, the idea of internships at industrial laboratories working on optical fiber systems never worked out as we planned. While Corning, Tyco, and Ciena all agreed to participate, our students by and large were not eager to participate. The basic difficulty is that the work that students could do at these companies was proprietary and, hence, not publishable. Only publishable work can be used by students as part of their Ph.D. dissertation. Consequently, internships at companies would slow down the process of earning their degrees. Our students preferred to expedite obtaining their degrees in order to be able to compete for regular jobs more quickly. The one exception is that in the last year of the program, one Ph.D. student, now Dr. Ruomei $\mathrm{Mu}$, did an internship at Ciena. Ciena was able to supplement her student stipend, which made the offer attractive. When she graduated, she received a job offer from Ciena as well as seven other companies.

In our last report, we noted that all of our previous research associates had left. We have recruited four replacements, all of whom are doing well. One of them, Dr. John Zweck, is already managing our partnership with Science Applications International Corporation.

Our focus on fostering research partnerships with companies has been highly successful. The most important of these partnerships is with Ciena. In 2000-2001, they provided us with equipment that would be worth well in excess of $\$ 1,000,000$ if it could be obtained. Much of it could not, in fact, be purchased. In return, we designed joint research projects that would produce results of interest to Ciena. All of our experimental students and two of our theoretical students are participating in this project. They present results regularly to our colleagues at Ciena and get feedback as to what issues are industrially important; so, this project has been very successful. Due to the problems in the telecommunications industry in the last year, Ciena is not supporting us financially this year. However, they 
are allowing us to keep the equipment in return for continuing our review meetings, and they have assured us that they intend to renew financial support when times improve.

Another partnership that we have is with Science Applications International Corporation. This partnership is based on their interest in our work on reduced models for modeling polarization effects. In the past year, we have developed our own software suite, and the portion that contains our reduced polarization models was developed with their support. We are currently negotiating a license with them that will allow them to market this software.

A third important partnership is with PhotonEx, a startup that is located in Maynard, $\mathrm{MA}$ and is making $40 \mathrm{Gbs}$ systems. Dr. Menyuk is working with them as their Chief Scientist, and several other UMBC students and scientists are collaborating with them mostly on modeling issues.

In our last progress report, we described interactions with fifteen different companies. Despite the current difficulties in the telecommunications industry, many of these interactions have continued. Since we already reported these interactions, we will not describe them again in detail. We note however that companies from whom we have received support in the past year, besides Ciena and Science Applications International Corporation, include $\mathrm{KDD}$, a producer of undersea telecommunications equipment, and Virtual Photonics, Inc., a producer of software for telecommunications systems modeling.

\section{Future Perspectives}

Using the PAIR grant as a base, we have been able to build up strong interactions with a number of companies. These interactions have increased the visibility of our research program and have given our graduate students special opportunities to present their work to companies that graduate students do not ordinarily receive. While we are disappointed that the program will not continue, we believe that the benefits to our program and to our students is permanent. Not only have the students who directly participated in the program benefited, but we believe that future generations of students will benefit as well.

In the future, we see the interaction with Ciena continuing to grow, and we believe that there is excellent potential for a growing relationship with KDD. We are negotiating licenses for our technology with Science Applications International Corporation and Virtual Photonics, Inc. We expect to begin licensing negotiations with PhotonEx to license one of our patents, and Phaethon Telecommunications has licensed a patent that we hold jointly with the University of Southern California. As the telecommunications industry comes out of its current slump, we expect our interactions with these companies to grow.

It is our view that the PAIR program was, in our case, a great success. 